\title{
THE POST-MORTEM ADMINISTRATION OF WEALTH
}

Death is the great conveyancer. To-day we own our property, to-morrow death works a transmission to others. It fulfills the conditions upon which settlements and trust deeds depend. It sets in operation the law of intestate succession and gives effect to wills. Thus in our own country property to the value of billions of dollars passes each year under some form of postmortem administration. In all such administration trust companies have a peculiar interest, but for the sake of simplicity let us confine our attention to testamentary administration and consider our subject from the viewpoint of a person about to make a will.

The first requisite of a proper testamentary administration is a properly planned will. The second requisite is a carefully prepared will. The third requisite is the selection of proper executors and trustees.

The first thoughts of a person about to make a will relate to its plan-(I) what property he may give, (2) to whom he will give it and (3) whether his gifts shall be absolute, conditional or in trust. With these points in mind the wise testator seeks sound legal advice. He remembers that many things, expected and unexpected, may or may not happen before or after his death. The amount or character of his property may materially change. His real estate may be converted into personal property or vice versa. His securities may be paid off or otherwise changed. in form. The value of his property may increase or decrease. Innumerable changes may occur through marriage, birth or death, among the objects of his bounty. His own condition may change so that he may no longer have capacity to amend his will to meet new conditions as they arise. In short, not only probabilities, but possibilities, must be considered and the will planned accordingly.

In the preparation of no legal document is the inaccurate use or location of a word or phrase more serious than in a will. Under the most favorable conditions every person experiences difficulty in writing the English language so as to convey his exact meaning beyond the possibility of a misunderstanding or a double reading. In testamentary writing this difficulty is in- 
creased tenfold, for the writer must look into the future and prepare an instrument which is to deal with such conditions as time may bring to the testator, his family and estate.

A will cannot be insured against a contest as can a house against a fire. The only known method of insuring a will is to employ the most skillful of professional experts to draw the will in the first instance, or to vouch for its accuracy before death renders amendment impossible. No one can prevent judicial inquiry into testamentary capacity, but much may be done to prevent disputes concerning the meaning and legal effect of the instrument and to render litigation improbable. The will of Samuel $\mathrm{J}$. Tilden is a far-famed, but unfortunate, example in testamentary writing of what "might have been." It is not generally known that in scrutinizing that will the late James C. Carter pointed out the very defect that proved fatal and that the governor's failure to make the correction was due to his procrastination in directing Mr. Carter to prepare an amendment. As Hon. John Bigelow puts it, Governor Tilden was "surprised by death before he had executed his intention to profit by the counsel" of Mr. Carter. Thus it appears that a letter or telegram from Greystone doubtless would have saved the Tilden will.

Trust companies, as prospective executors and trustees, have a special interest in proper testamentary writing that they may accept such trust business as comes to them without being subjected to unknown liabilities in the performance of duty. Consequently, they have done much for the betterment of testamentary writing, but still the safe and sound will is the exception, rather than the rule. In America, where testators subject their wills to a rigid critical interpretation before death, fully three out of five discover satisfactory reasons for making amendments. Most testators, however, seem to proceed on the theory that it is better to let their estates take the chance of defending a cheap or home-made will at any cost rather than themselves to take the necessary steps to insure a proper document. Thus it is that an undue number of estates pass under defective or ambiguous wills, creating family feuds and paying what may be termed salvage to the legal profession.

Americans do not appreciate the value of constructive law. American lawyers and law schools need more to emulate English patience and perseverance in the preparation of legal documents. Their attention is riveted upon the remedial at the ex- 
pense of the constructive. While in case of disaster the proper handling of a wreck is as necessary in law as at sea, constructive law is of equal if not greater public utility, for it insures peace and prosperity and. in the case of wills, prevents disruption of families and a ruinous waste of assets. Constructive law should receive more attention than it has in the past, and law schools should aim to turn out architects-at-law as well as masters of the remedial arts.

When laymen and their advisers are more fully alive to the importance of better testamentary writing, litigation concerning wills will be materially less, testators will act with more confidence, families will be more harmonious, beneficiaries will fare better and executors and trustees will be more free from personal liability.

Let us now consider from the testator's view the human agency upon which he must rely to carry the plan of his will into effect. We must accept the testator's point of view, for he is entitled to make his own selection. When a person makes a will and selects his executors and trustees he has several courses open-(I) he may select one or more individuals with or without bond; (2) he may select a trust company to act alone, or (3) he may select a trust company jointly with one or more individuals. Each one of these agencies has some advantages and some disadvantages over the other two. We cannot say that one of these agencies is always better than another, for the personal equation varies with each selection. We are told that nature has not produced a perfect blade of grass, a perfect flower or a perfect fruit, and we might add that human nature has never produced a perfect trustee; but as one blade of grass, one flower, one fruit is more perfect than another so among trustees the testator has room for choice.

The duties of executors and trustees are twofold-they are not only business and financial, but also human and personal. A testamentary trust is more than a business; it carries with it a confidence. Under some wills the business and financial sides predominate, but there is always present a feature incident to the lives, character and welfare of the beneficiaries. This element of post-mortem administration demands a most delicate touch of human kindness, sometimes even paternal in its nature, often sought and too seldom found. The executor and trustee, whether individual or corporate. should command the respect 
and confidence, not only of the testator, but also of the beneficiary. Whether an individual or a corporate official, he should be one to whom the beneficiary not only may, but will be likely to, go for counsel and advice. In short. he should be one who will take a personal interest in the welfare of the beneficiary, and conscientiously, with gentleness and firmness, carry out the wishes of the testator as the first law of his being.

The prime factor in post-mortem administration is the safety of the estate. It often determines the selection of executors and trustees. The old method before the days of trust companies and surety companies was to rely upon the character and financial standing of the individuals appointed, supplemented in some jurisdictions by individual bonds. Such appointments have been the occasion of much unsatisfactory administration. They have resulted in loss both from embezzlement and dereliction of duty. To secure safety from these hazards trust companies and surety companies have each offered a solution which has proved satisfactory to many testators.

The plan advocated by surety companies is the appointment of individuals of known character and business ability under a legal or testamentary requirement that suitable bonds be furnished, preferably by a surety company at the expense of the estate. Such testamentary provisions are sometimes inserted at the request of prospective executors and trustees on the ground that the joint control of assets and the accompanying supervision of surety companies is an aid to proper administration, a protection against mistakes and a safeguard against the negligent or wrongful acts of employees or of a co-executor or co-trustee. The bonds thus advocated guarantee the estate against loss arising from dereliction of duty as well as from misappropriation of funds.

The plan advocated by trust companies is their own appointment with or without the addition of one or more individuals as co-executors and co-trustees. If a trust company is appointed its capital and surplus stand as a guaranty for the performance of its duty, but not as a guaranty for the performance of duty by a co-executor or co-trustee. Where the possibility of loss through a co-executor or co-trustee is not cut off by a surety company bond it is generally well hedged about by a trust company for its own convenience and protection. The practice of trust companies acting as co-executors or co-trustees in assuming 
the custody of securities is in itself an important element of safety. Some testators insert provisions in their wills looking to this end, often to the relief of their individual executors and trustees.

Both plans of safety involve a corporate custody of securities, in one case joint and in the other absolute. They differ in that the liability of the surety company is limited to the amount of its bond, while the liability of the trust company is co-extensive with the estate. The difference also extends to compensation. The former receives an annual premium as for insurance, while the latter receives no compensation except for the performance of its duty as executor or trustee.

In England a new feature has been injected into trusteeship. Corporations with powers somewhat corresponding to our trust companies are sometimes appointed custodian trustees for the purpose of holding securities subject to the trust, while the other duties of the trust are performed by individuals known as managing trustees.

Experience has shown that both surety companies and trust companies under proper capitalization and management offer excellent plans for reducing to a minimum the possibility of loss attending post-mortem administration. Thus the testator has at hand ample means for the protection of his estate from dangers to which it would otherwise be subjected.

To insure an estate against loss from embezzlement and dereliction of duty is, of course, a wise precaution, but it is wholly negative in character. The testator seeks affirmative qualities. $\mathrm{He}$ demands sound judgment, wise and efficient management during the whole term of the administration, but, above all, at its inception, when an unwise exercise of discretion has often resulted as disastrously as embezzlement or dereliction of duty.

The first duties under a will are performed by the executor. After a thorough study and understanding of the will he realizes on the testator's assets, pays his debts and distributes the surplus or turns it over to trustees for investment according to the terms of the will. Where the duties of executors end the duties of trustees begin. The executor turns over the trust estate to the trustees in such form as the will directs. The trustee must thereupon review the state of the investments and square them with the law and the terms of the will. If under the will the executors have already performed that duty the task of the 
trustee is much reduced. Thenceforth the duties of the trustee are those of investment and reinvestment and the collection and application or payment of income. Thus it is that the duties of executors are less routine in their character, more difficult to perform and more temporary in their nature than the duties of trustees. Consequently testators are disposed to look more for mature experience and discretion in the selection of executors and less to longevity. In the selection of trustees testators, in a large measure, seek the same qualities with an added care for a continuity of the trusteeship during the trust term. The element of personal interest in the beneficiaries is usually more or less present in the mind of the testator in the selection of both executors and trustees and is frequently a determining consideration, sometimes even at the expense of good business administration.

While in the selection of individuals as executors and trustees the testator has a wide range of choice, there are certain qualities which he cannot overlook. He must have integrity and ability and should have good business habits. In selecting such persons the testator usually relies on personal acquaintance, observation and reputation. He looks with confidence upon persons of good personal habits and associations, upon males rather than females, upon married rather than unmarried men, upon the man who has no adverse interest. who is morally sound, whose family is not extravagant, who has a means of livelihood, who does not live beyond his means, who has good and regular business habits, who is moderately successful, whose business is not speculative, who does not buy and sell on margin, who has a mind of his own but is not self-opinionated, and who is free from prejudice, capable of discrimination, sound in judgment and considerate of the rights of others.

This may be a high standard to set for post-mortem administrators of wealth, but to me it seems to be the true one. It certainly is one the testators are continually applying and, therefore, should receive serious consideration in the selection of directors, officers and employees of a trust company if it is to attain any degree of success in this important branch of its business.

In selecting executors and trustees the mind of the testator usually turns first to his family, then to his friends, business associates, legal advisers and trust companies. In his family he is most likely to find an element of personal interest which 
strangers do not possess. Yet so frequently are other qualities absent that no general rule can be stated as to the wisdom of placing post-mortem administration in the hands of kindred. So much depends upon the individual, the estate and the will that each case must be a law unto itself.

Fortunately, the testator is usually the best fitted to judge of the situation. For example, if the testator's estate is small and is given absolutely to his wife she practically becomes the owner of the surplus and under ordinary circumstances she may well be entrusted with power over her own. If, on the other hand, the estate is large or somewhat involved or trusts are present in the will the necessity for outside assistance becomes more apparent.

Where the will contains no trust, and the corpus is to be divided on the settlement of the estate usually there can be no objection to the selection of executors because of interest or kinship. Where business qualifications, honesty and ability are sufficient and family jealousies 'not likely to be aroused such appointments are eminently proper. If, however, the will contains a trust very different considerations necessarily enter into the selection of a trustee. Thus a beneficiary, whether a lifetenant or remainder-man, is an unfit person in law and in fact by reason of interest. Near relatives are objectionable for the same reason and because they are "less able to withstand the importunities of beneficiaries." In the same way, where a husband, wife, parent or other near relative is appointed trustee such relationship "is too often made an excuse for lax management, and the knowledge that a breach of trust is likely to be condoned not infrequently leads to a disregard of strictly legal management, which is the only safeguard of trust estates."

In many respects the legal adviser is the logical executor and trustee of his client's estate. It is a recognized part of his business. $\mathrm{He}$ is acquainted with its duties and obligations. $\mathrm{He}$ is the testator's confidential adviser in all domestic, personal and financial affairs. He is acquainted with the wishes, purposes and estate of the testator more intimately than any other person. $\mathrm{He}$ is accustomed to weigh reasons and to advise in difficult situations. His mind is usually more free from prejudice, more amenable to reason and less subject to undue influence of a beneficiary than a person otherwise situated. If wise in counsel and clothed with power and discretion he is often an important peacemaker between adverse interests. 
Nevertheless, the lawyer has the frailties of human nature, and trust funds are not always safe in his custody unless he gives ample bonds for the performance of his duty. Where however, lawyers are competent and honest the English practice of making the testator's solicitor one of his executors and trustees has probably given more general satisfaction than the selection of any other class of individuals outside of his immediate family.

Trust companies have earned an excellent reputation as executors and trustees and offer valuable qualities to the testator. They offer security of assets, continuity of existence, experience, business management, readiness of access, opportunity of favorable investment and due consideration for beneficiaries. In these respects the record of trust companies as a whole is most satisfactory and honorable. Where, however, trust company management is open to criticism its defects relate to individual companies rather than trust companies as a class and arise from undue routine in business, undue pressure of business on individual officials, disinclination to assume liability, a lack of proper self-inspection and the unfortunate selection of directors, officers, counsel and employees. Vigilance in these matters is soon discovered by testators, and is the price of corporate success in testamentary administration.

While the character and general reputation of a trust company is often responsible for its appointment, yet in very many cases the personnel of its management is decisive. Of the importance of the personal element in a trust company there can be no doubt; it is much more the subject of discussion among testators and their counsel and more often the determining factor than is generally supposed.

Hon. Lyman J. Gage has well described the situation. $\mathrm{He}$ says: "Character and capital are the best assets of a trust company. Its officers and directors, therefore, should be men of wide experience, men who have been tried and who devote themselves with honorable zeal to the high duties of their positions."

Generally speaking and without specifying particular situations or testamentary conditions, the best results seem to have been attained in post-mortem administration of substantial estates by combining as executors and trustees a trust company and the testator's counsel, sometimes alone and sometimes joined with one or more of the testator's family or friends. Thus are se- 
cured the advantages of corporate management as well as personal responsibility and individual discretion.

This is not merely a personal view. It is the opinion of many persons, including some of the greatest financiers in this country. To quote again from Mr. Gage: "Where the family counsellor acts with the trust company as co-trustee advantages are obtained which explain in a large measure the success of the trust company." I might add that it is often an inducement for counsel to act if they know that they are to have the co-operation of a first-class trust company, with its experience and facilities for receiving and paying out money, making investments, safeguarding securities, keeping accounts and otherwise handling a multitude of details more or less burdensome to an individual.

Whatever we may think or say concerning executors and trustees the fact remains that administration of property after death depends primarily upon the testator. He may direct it into any channel giving or withholding such directions, powers and discretions as seem to him best. As he has the power he must accept the responsibility. If he plans his will wisely, makes sure that it will stand the strictest scrutiny after death and selects his executors and trustees carefully, requiring bonds where desirable, he may reasonably expect satisfactory results, but not otherwise.

The trust company after adopting proper business methods and squaring the human agency behind the corporate name with the qualities which carry confidence and make individuals desirable for positions of trust, can render no greater service to itself and to the interests it is to serve than by educating the public as to the importance of a sound will and the advantages of corporate administration after death.

Dariel S. Remsen. 